\title{
"I had no idea such people were in America!": Cultural Dissemination, Ethno-linguistic Identity and Narratives of Disappearance
}

\begin{abstract}
A NDREW GOW
The image of the American melting pot has been enormously influential among both dominant American and other elites facing the dual pressures of needed immigration and demands for the assimilation of recent immigrants. ${ }^{1}$ Current German has also adopted the metallurgical term Schmelztiegel (melting pot) in a sociological sense, and there has been a certain amount of talk about Überfremdung - being overwhelmed by the foreign - as a danger in a society that allows in too many immigrants, who putatively remain foreign because there are too many of them to be assimilated. This organic metaphor is reminiscent of the physics of super-saturation and dissolution of solids in liquids, as though humans were primarily quantities rather than qualities. There has been considerable recent public debate about the necessity of immigrants to assimilate into what some right-wing Germans call the 'Leitkultur' ('the guiding culture' or normative majority culture) in France, Germany, Austria, and more recently in the Netherlands, Denmark and Sweden. The 2005 riots in France led to calls from the right for the further 'assimilation' of the children of North Africans. On the other hand, the multicultural 'mosaic' image, much used in Canada where it was constructed as an alternative to the symbolic violence of the melting pot, substitutes a reified continuing 'difference' for an imaginary produced 'sameness.' 2 Neither the pot nor the mosaic seems to accurately capture what immigrants actually do in new surroundings: for instance, neither term can cope with the long-term existence of 'minority' or transnational communities - for decades, for centuries, even for millennia - that do in some way become one with the surrounding culture, language, religion - though an immigrant minority may well
\end{abstract}


take on various aspects of the host culture while rejecting others, thus becoming hybrid. A number of examples will illustrate these points in this paper: Jewish communal cohesion in diaspora (especially the diasporas of Central European German- and Yiddish-speaking Jews); the long existence of German-speaking communities, Christian and Jewish, in North America, that had fallen silent by 1917; and European (mis)conceptions about these diasporas past and present and thus about the composition and texture of new world societies.

One of the first things that strikes educated, urban North Americans visiting western and especially Central Europe for the first time is the ethnic and racial homogeneity that still is the rule outside of certain parts of certain large cities - in comparison, of course, with North American cities and towns (only certain areas excepted). Post-war Europe was divided into nation-states that were supposed to separate ethno-linguistic 'nationalities' and thus avoid the 'nationality problems of nineteenth-century and pre-WWII Europe (e.g., German or Italian nationalism; the 'nationalities' of the Austro-Hungarian Empire; Serbian nationalism as a trigger for WWI, etc.). Most Central European nationstates were much more homogeneous (linguistically and culturally) after WWII than their predecessor states had been. For example, the bilingual societies of what is now north-central and western Poland were split up into 'Germans' and 'Poles,' or in the Baltic into 'Germans' and others, and then those identified as Germans were driven westwards across new frontiers. These newly arrived inhabitants in the Germanies were now to be 'German refugees from former German territories' (rather than, say, trilingual Kashubes with German last names who had been identified or identified themselves as Germans at some point), or even monoglot German-speakers with Slavic last names from territories of mixed ethnicity. Of course, almost all the Jews of Central Europe were gone - murdered or emigrated - by the time the new nation-states were 'up and running.' The disappearance of Jews was a major part of the ethno-linguistic homogenization of Poland and of what are now Lithuania, Ukraine and Romania, to take the most obvious examples.

By way of contrast, let's assume that 'identity' seems to run along relatively more complicated and intertwining channels in diaspora societies (whatever the underlying complexities of post-war Central Europe actually were). Standard models of cultural dissemination core to periphery, metropolis to provinces - are generally used to try to explain diasporic cultures (both in recently fashionable post-colonial theory and in the colonial discourse from which the former has not yet 
freed itself), but I submit that such models are both inaccurate and misleading when applied (at least) to the instances of diasporic identities and cultures I shall present below. The recent emergence of 'transnational' 3 studies and approaches in deliberate contradistinction to the 'international' (which suggests contacts among discrete national entities or among their [homogeneous] 'nationals'), is a promising step in the direction of finding terminology and institutional loci for the study of hybridity at the social and political level - though, as Young-Sun Hong put it in a recent forum on transnationalism, "Some of the most successful transnational history to date has focused on immigration, hybrid identities, and various forms of 'double consciousness.' 4 It is precisely in the realm of 'culture,' then, that transnational approaches seem to have been most useful (Hong suggests they have yet to prove as useful in the study of other phenomena). Yet unless we pay attention to local manifestations of 'transnational flows of culture,' according to David Palumbo-Liu, the uncritical use of concepts like Bourdieu's 'cultural capital' will lead us to reproduce dominant 'globalizing' interpretations of cultural flows and interactions (centre-periphery, etc.) in such a way as to occlude lived practice. ${ }^{5}$ Religion, ethnicity, language, gender, culture, and class constitute and maintain 'other' and especially hybrid identities in diaspora.

\section{THE JEWISH CASE}

Central European diasporas are in a sense more diverse than most of what is now Central Europe, after the ethnic 'cleansing' or rather division that occurred after WWII. Such diasporas include the enormous Jewish dispersion from Central Europe to the new world, beginning in the middle of the nineteenth century. The multiple Jewish experiences of diaspora show how strong religious and social networks working to ensure linguistic and cultural cohesion and Hebrew learning can guarantee 'difference' and simultaneous hybridity over millennia. Eric Hobsbawm has recently restated the argument that the oppression exercised by anti-Semitic societies and the (internal) repression produced by ritual and other rabbinical constraints produced a kind of cultural-hothouse out of which newly emancipated Jews burst onto the 'modern' (nineteenth- and twentieth-century) western world, making huge contributions or even shaping entire fields in the arts, politics and especially the natural sciences. He contrasts this with the relatively low number of Jewish Nobel winners raised in Israel, suggesting that 
(Gentile) oppression and repression can be culturally 'fruitful' - "as though the lid had been removed from a pressure cooker" ${ }^{6}$ While I am profoundly skeptical of his ascription of causality to oppression in this Freudian (and slightly self-congratulatory) vein, the phenomena he addresses suggest some interesting questions.

The example of the Jewish diaspora might be an extreme case, but calling to mind in microhistorical fashion the practices of Jewish resistance to assimilation (especially since 'emancipation') might provide us with some models for productively queering the normative sociological and demographic frame through which social scientists approach the seemingly binary issues of assimilation and cultural continuity. 7

\section{MODELS AND NARRATIVES}

The classic modernist understanding of diaspora communities as first insular, isolated and "ghettoized," then assimilating, and finally assimilated was described in 1951 by Oscar Handlin in The Uprooted. 8 My goal here is to undermine or at least complicate such triumphalist teleologies by presenting evidence of the flourishing historical condition and continuity of German-speaking and other linguistic diaspora communities. This might allow us to approach seemingly anomalous 'survivals' from a perspective that does not emplot them into the triumphant process of leveling, assimilatory progress; that does not begin merely with surprise at the existence of a phenomenon which the model of assimilation assumes a priori to have disappeared.

\section{MAKING “GERMANS" IN EUROPE AND NORTH}

A MER I C A

In a discussion with a distinguished German professor in August of 2005, I was asked how I learned to speak German without a 'foreign' accent. Because I have been asked this question many times, I have a ready-made account to riff on, according to the circumstances. I went over the history of German-speaking Jewry since around 1700, in Germany, Britain and North America, situated my family in relation to some well-known and some lesser-known aspects of the German-Jewish diaspora, including various odd twists in the twentieth century that led to both structural and personal factors: my bilingual French-and- 
English-speaking early childhood in Montreal and my exposure to other languages at home (primarily Middle English via Chaucer, but also German, Yiddish and even a bit of Flemish). This led to a broader discussion of German-speaking diasporas in North America, of which he was vaguely aware, but not in detail. ${ }^{9}$ I cited as local examples of the countless German-speaking communities in North America the functioning, germanophone Evangelisch-Lutherische Dreieinigkeitskirche, (founded in 1914, as the cornerstone notes), at the corner of 100th St. and 83rd Ave. in what was once the German quarter of Edmonton (Alberta, Canada), along with the nearby Evangelische Freie Kirche on 85 th Ave. between $100^{\text {th }}$ and $101^{\text {st }}$ Aves., both of which have German-language services every week; 10 Hutterite outings to West Edmonton Mall with window-shopping or running the little remote control boats, and discussing these things in Low German in slightly hushed tones; the German-Jewish community of late nineteenth-century Chicago, where most Jews spoke German until the 1870s; 11 the German-language newspapers and publishers of cities with large German populations like Milwaukee ${ }^{12}$ and St. Louis (including the highly productive branch of the publisher Herder Freiburg in the city of Anheuser-Busch's "Budweiser" brewery, itself a folly in brick and glazed tiles in the style of Wilhelm Busch's Max und Moritz cartoons13), to Shaar HaShomayim,14 founded in 1846 as a German-Jewish alternative to the only other synagogue in Montreal, an 1768 English-Sephardic offshoot of New York's Shearith Israel (1654).15 My learned interlocutor's reaction was "Ich hatte keine Ahnung, dass es in Amerika solche Leute gibt!" This reaction struck me as a condensation of all the faintly incredulous, outright disbelieving or simply flabbergasted reactions I have experienced from Germans (esp. those born and raised in the former West Germany, a.k.a. 'Bonn Republic') confronted with the vast, rich and quite lively North American cultural and linguistic diversity in general and of the North American germanophone diaspora of both recent and older vintages in particular. The general assumption is that 'German' immigrants (broadly, German-speakers from anywhere in Europe, from the Vosges to the Volga) have assimilated quickly and lost their mother tongue within one or at the outside two generations. This is, indeed, true enough of many post-1945 German-speaking émigrés, many of whom were deeply ashamed of their ethnicity, its role in the recent Holocaust and in other imperial adventures and who wanted nothing more than to disappear into middle-class Anglophone society. My learned interlocutor, a native of West Germany who teaches in another 
germanophone state, clearly was thinking of this national/anti-national diaspora and its well-known effects. In my experience at least, the middle-class West German without at least one aunt, uncle, cousin or more distant relation in Canada or the USA is a rare bird. Experience of these close affiliates, paired with an integralist understanding of nationality, language and ethnicity, dominate 'West German' perceptions of the German diaspora. Rare indeed, on the other hand, is the contemporary German with links of any kind to the substantial and well-established German-Jewish communities in cities like New York, Philadelphia or Montreal, or to Mennonite, Hutterite or Amish diasporas - all these having arrived in America long ago and having left little or no trace in post-war Europe, never mind Germany. Thus, postwar concepts of nationality, ethnicity and linguistic identity - the expression of an ethnically 'cleansed' (judenrein) post-war Germany and of states and populations that had been arranged deliberately to avoid 'nationality questions' by excluding non-national native minorities (Slavs and Balts having become majorities by virtue of mass deportations of people who were suddenly "ethnic Germans" in formerly German eastern territories; as well as of German Silesians, Sudeten-Germans, etc. ${ }^{16}$ ) - shaped not only the identity of post-war Germans, but also their perceptions of the germanophone diaspora. I have been insisting on 'West Germans' so far because Germans who lived or grew up in the former German Democratic Republic are less likely to be surprised by all the varieties of cultures, communities and groups that existed, largely unknown to them, outside of East Germany: Hutterites in Alberta or German-speaking Jews in New York were no more exotic than the hitherto-unimagined bourgeois gay men, socialist Catholics or naturalized German-speaking African-Americans they quickly encountered, after 1989, in West Berlin and the former Bonn Republic.

How, then, have Central European ethno-religious/ethno-cultural diasporas extended over time and geography to the Americas? And to what extent does ignorance of them or dismissal of them in Europe grow from ethno-religiously 'homogeneous' European cultural experiences as formed by corresponding exclusivist national-linguistic and cultural hegemonic blocs (e.g., post-war 'Germanness,' Fifth-Republic Frenchness?). Do nationalist articulations of cultural capital actually obscure or forcibly simplify transnational experience and practice?

I have noticed that uneducated, educated and academic Europeans chiefly German, French, Austrian and Polish - have a certain difficulty 
with imagining (and not merely an ignorance of) the existence of the many ethno-religious and/or ethno-cultural diasporic communities from Central Europe in the Americas. Although educated Germanspeakers (esp. Protestant ones) tend to know of the existence of the Mennonite, Amish and Hutterite diasporas, ${ }^{17}$ they cannot quite imagine that such people speak German or Low German today, teach it to their children, read German Bibles, and conduct church services in one of those languages. Not merely religious heterogeneity but also the archaic forms of Low and High German spoken by 'Anabaptists' cut across national self-understandings: Low German speakers in diaspora reproduce the transnational linguistic community of Low German speakers that extended from Flanders to Tallinn and from southern Denmark well down the Rhine and Elbe in the Middle Ages until the development of distinct Netherlandish (and much later Belgian) and German national identities in the early modern period. Thus Anabaptist speakers of various 'Germans' in diaspora constitute transnational phenomena that transcend national categories and are simultaneously hard to perceive/conceive of from within contemporary national (German, Dutch, Flemish) self-understandings. ${ }^{18}$ As for the other major ethno-religious/ethno-cultural diaspora from Central Europe, the (formerly?) German, Austrian and Polish/Galician/Ukrainian Jewish communities, their existence in Canada, the US, Mexico and Argentina now functions simultaneously as an exotic reservoir of 'Europeanness' to young Europeans fascinated by klezmer, or by the New School, 19 and as a dark shadow of reproach in a simultaneously guilt-ridden and antiZionist Europe. In Europe, details about such communities are sketchy, if available at all. Usually, such emigrants and exiles and their descendents are read simply as 'Americans' or 'Argentinians,' in imitation of unitary national-identity tropes that have become naturalized in Europe, especially since WWII and the ethnic segregation that resulted from it. Since Americans are, in some varieties of the popular European imagination, and oddly enough especially to progressive intellectuals, monoglot devotees of fast-food corporate culture, oafish suburbanites devoted to huge vehicles, afflicted by bulging waistlines and coarse tastes in clothing, furniture and cheese, it can be difficult for Europeans to imagine continuing expressions of 'foreign' language and culture as anything but doomed survivals: the three public elementary schools in Edmonton today in which children are taught in English and in German (not to mention the dozen or so other languages taught in the context of such bilingual public schools) are 
a great deal more than just 'survivals'; they are perhaps 'revivals' but they are powerful vectors of a functioning ethnopluralism.

Contemporary European stereotypes of North Americans also make it difficult for Europeans to imagine seventeenth-century utopian pietists singing German hymns in an ethereal counterpoint in the Ephrata commune (in Pennsylvania), German Jews keeping business records in (Judeo-)German (as some of my ancestors did for many decades in Lower Canada/Québec in the eighteenth and early nineteenth centuries) or reading Goethe or Walther von der Vogelweide; the hundreds of public schools in Ontario in which German was the primary language of instruction until WWI, when the infamous Bill 17 closed down all 'foreign-language' schools (including, unconstitutionally, French ones; as well as the many Gaelic ones); the bilingual German-English schools of Indianapolis, where the American national anthem was sung in German until 1917.20 These are, admittedly, all of a lost past. Yet had World War I not required many German emigrants to choose between the new country/language/culture and the old, German might still be the automatic second language of educated Americans and Canadians, as it was in the later nineteenth and early twentieth centuries, and the first language of millions of American- and Canadian-born 'Germans' meaning people of various 'germanophone' regional descent, 21 including Austrians, Swiss, and Germanophone Jews 22 from all over central and eastern Europe, etc., as it was a hundred years ago. A recent study by Russel Kazal demonstrates how the largest German community in America, in Philadelphia - coincidentally also the one with the deepest historical roots - came to a dead end in WWI (though he argues that it was already losing its bicultural character by the 1890s.)23 The rupture or laceration, the deep cut, that was the abrogation of German learning and culture as a viable second 'national' tradition in America would seem to me to be one of the deep emotional engagements that helped fuel and maintain a certain visceral germanophobia in the post-1945 American public.

In 2003, I used some of these examples to try to persuade a young German candidate for the Lutheran ministry - a long-haired, barefoot hippy type, yet paradoxically deeply conservative in a Bavarian way, and convinced, like so many of his fellow-Europeans, of the superiority of 'European' culture to everything 'American' - that he was deeply misinformed about Amerika. What seemed to persuade him was my recounting of the sheer variety of learning, of linguistic competence, of cultural diversity and attainment to be found in just about any North 
American city. He had been thoroughly taken in by the worst televisionfuelled fantasies about the monoglot, low-brow Ugly American. These are sometimes supported by fleeting visits to tourist centres in the US, though more often not. Such images serve as a foil and 'other' to bolster congratulatory, self-proclaimed 'cosmopolitan European' self-images rooted in, say, nostalgic Rive-Gauchisme (a Sartrean [geographic] simulacrum of a practical progressive politics), in a retrograde fetishization of 'humanistic' education (available only to a small minority anywhere, ever), or in fantasies of multi-ethnic harmony in imperial Ruritanian utopias: in these latter cases, Timothy Garton Ash's vanished high-brow Mitteleuropa thus functions as a tragic foreshadowing and antithesis of omnipresent low-brow Mittelamerika.

Reality often looks very different. For example, the hundreds of first-, second- and third-generation (or longer established) German-speakers, Jews such as Donald Weinstein (professor emeritus of history at the University of Arizona) and non-Jews alike, who served in the Englishand French-speaking Allied Armies during the second World War and acted as translators and liaison personnel in Germany after the war seem to have left no impression or popular memory behind in Germany at all. The occupiers would all seem to have been the standard-issue lower-middle-class G.I. type familiar to Germans from the many US bases in the post-war era. Such germanophone Allied personnel simply did not fit normative categories of Amerikaner, Kanadier or Briten and their substantial numbers on the ground in 1945 and 1946 is as forgotten as those German-speakers' forebears are. Statistical norms have thus been allowed to determine, in a chillingly völkisch twist, what is 'normal' - typisch - for a given 'people,' post-war Germans reading other 'peoples' as they saw and see themselves: culturally, ethnically and linguistically homogeneous (or rather, homogenized). When mainstream discourse is so oblivious to minority cultures, both imagination and action are determined by a certain tyranny of the majority; and while people of many cultures tend to view other peoples as a function of the typical, the majority (I am doing so right now), I think this is especially true in Germany.

GERMAN, GERMANS, YIDDISH AND JEWS

When I have described the continued, if somewhat diminished use of German by German-descended Jews in North America as well as the 
widespread use of Yiddish as a daily language in many American communities (e.g., the Ashkenazic Jews of Mexico City, aged secular Jews in Miami and Manhattan, and of course, Chassidic Jews all over the Americas), Yiddish newspapers in New York, Buenos Aires and elsewhere, or of Jewish day-schools in Mexico City in which the primary language of instruction is Yiddish, western and central European interlocutors have been astonished that such things still exist - reading them as mere 'survivals' of something that is obviously doomed, as 'Auslaufmodelle', rather than as vibrant and continued ethnic, cultural and religious practices that result, among other things, in resistance to homogenizing influences. ${ }^{24}$ That anyone speaks or writes Yiddish at all today is, after all, rather more than evidence of 'survival' - it is a continued bold affirmation and act of resistance. More and more young Americans are learning and reading Yiddish. ${ }^{25}$

It would seem that ethno-religious groups (Jews, Anabaptists) are more apt than ethno-cultural ones to maintain linguistic and cultural distinctions from their host societies, but this is not necessarily the case. I propose that the relative ethnic and cultural homogeneity created in Central European nation-states in the blast-furnace of the second World War estranges Central Europeans as much or more from their putatively "pluralist" Central European past as it distances the members of these diasporas from theirs. In his recent book Postwar. A History of Europe since 1945,26 Tony Judt lauds the various members of the EU for what he imagines to be their new openness to ethnic and cultural diversity, their establishment of a new model of non-national polity that will do away with the absolutisms of the traditional nation-state (the Jewish version of which he condemns for various reasons not limited to his antinationalism). Muslims, Sikhs or Jews forced to doff their religious headgear in all French state schools might tell a different story, as might teachers (except nuns, who are exempt!) in Baden-Württemberg, who are also forbidden from demonstrating outward signs of religious allegiance or observance. I think the majority of Turkish guest-workers in Germany do not feel like they are living in a post-national age of easygoing diversity, and I even wonder if they would desire such a thing.

National categories produced in obedience to the obligatory alignment of at least nation, state and language, and often also of religion, reach into the western European past and into the European present and future. The 'progressive' character of nationalism, arrayed against the reactionary 'multi-national' states confirmed by the Congress of Vienna, contrasts with the oppressive valences it developed 
in the later nineteenth and especially in the twentieth century. Despite its beginnings as a liberationist movement directed against the oppressive autocracies of the early nineteenth century, nationalism developed its own oppressive logic and methods. The language laws and school ordinances promulgated by Jules Ferry after the middle of the nineteenth century made France into something it had never before been, namely a French-speaking nation. The polyglot Britain of the later Middle Ages had become the English-speaking United Kingdom by the end of the eighteenth century. The middle of the twentieth century was marked by a paroxysm of pathological nationalisms in the form of National Socialism and other extreme nationalist-ideological compounds (Stalinism, McCarthyism). The nationalist imperative of cultural, linguistic and national alignment has exercised an especially nefarious influence in south-eastern Europe since 1991: only narrow modernist definitions of nationhood could have produced either the concept or the act of 'ethnic cleansing' in these long-standing 'mixed' polities. But the problem is not exclusive to the former Yugoslavia: both the western European nation-states and the new members of the EU have a long way to go before their national language, culture and borders cease to appear naturally coterminous. A certain shyness to project the existence of 'Germanness' outside the borders of 'Germany' after the imperialist adventures of the Third Reich is understandable, yet just such an expanded definition of Germanness remained anchored in the German constitution (Grundgesetz) until recently in a way that allowed citizens of eastern European countries who could demonstrate a modicum of German ancestry to receive German citizenship automatically upon application (while second or third-generation German-born Turks still cannot). One wonders why the same principle did not also apply to descendants of 'Germans' in other parts of the world (would Germanspeaking Mennonites or deitshe Yidden/Yekkes27 have qualified?). Linguistic and genetic criteria were hopelessly muddled in this instance, based as they were in part on the evidence and more importantly on the categories of Nazi-era Ariernachweise (proof of unmixed 'Arian' descent) and Stammbücher (family genealogical tables) which emigrants from the European east regularly presented as proof of their claims (and on census records from before WWI in which one's ancestors were registered as ethnic Germans). 


\section{A NTI-SEMITISM, TRADITION AND IDENTITY}

In sentencing Polish avant-garde artist Dorota Nieznalska, a trial judge condemned her work Passion, showing the image of male genitals on a large cross, as offending religious feelings. I am citing an English translation that appeared in Hysterics. An Online Art Magazine:

Article 196 of the Penal Code penalises offending religious sensitivities of others through offending an object of worship in public. It is doubtless that a cross and also the particular cross used for the Passion installation is indeed an object of religious worship, namely it is a symbol dear to Christians. Although Ms Aneta Szyłak pointed out as a witness for the Defence that the cross might as well be interpreted as the so-called Greek cross or as a cosmological symbol and that a cross is a symbol of suffering as such, it remains doubtless that in the Polish context, in the Polish tradition of civilisation, the cross is unambiguously associated with [the] martyrdom of Christ.

Furthermore, it needs indicating that it is this meaning of the cross that had been assigned to it in this particular installation by the very name it had been given by the artist. The artist titled it Passion which word does not only mean [sic] "commitment" but is as well associated with the martyrdom of Christ. Co-occurrence of the cross and the word unambiguously assigns perception of the cross as a Christian one. While a cross is indeed a symbol of suffering, it needs to be indicated that in the context of Christian civilisation it is so only for the reason that Jesus Christ died on one.28"

The "Polish tradition of civilization" is thus understood to be a uniquely Christian, mono-ethnic history, indeed a 'Christian civilization.' The large Jewish contingent of the Polish middle class before 1939, and of urban populations in Poland since the Middle Ages, is thus written out of the 'Polish tradition of civilization.' That millions of Polish citizens before 1939 associated the cross unambiguously with persecution and with the martyrdoms their ancestors suffered is a proposition that cannot co-exist with this utterly ahistorical reading of 'Poland's' past. In the context of European civilization, the crosses of the Crusaders, of the Rindfleisch massacres, of the massacres at Vienna in 1420-21 or Regensburg in 1519, of the Cossack Khmelnitsky Uprising, and so forth, were symbols of suffering not because Jesus died on one, but for very different reasons altogether. This judge's reading itself might 
well offend other 'religious sensitivities'; and it denies the historical complexity of 'Polish' history.

Jewish examples in the Polish context reveal some of that complexity. My mother's two oldest and closest friends, a married couple, were both born in Poland, one in a small Jewish town and one in Warsaw. Joshua Heilman grew up speaking Yiddish and Polish and reading Hebrew and Aramaic as well as Polish and Russian, but Polish was not his preferred language. The rabbi of the town in which he grew up, Lubaczow, spoke no Polish; and when, on the third of May each year, the Jews assembled in the Great Synagogue for a celebration of the Polish national holiday, the rabbi gave an address in Yiddish. Local Polish dignitaries in attendance could not understand him; and when the national anthem was sung, the cantor, who knew the melody but not the Polish words, just repeated the Hebrew ending to a prayer, ' $v$ 'nomar amen' (and let us say amen), until the anthem was over. ${ }^{29}$ But he knew the tune and he sang it like a good 'Pole'...

Anna Wajszblum ${ }^{30}$ grew up in Warsaw, daughter of leading industrialists. She was a Jewish Pole; she spoke Polish at home. She learned German in the Warsaw Ghetto and at Auschwitz, and Hebrew only after the war in Israel. ${ }^{31}$ Polish and Jewish identities flowed into each other in quite complex and contradictory ways, suggesting once again the inadequacy of both nationalist and centre-periphery models of culture.

These complexities were typical for centuries in Poland and eastern Europe: Jewish men spoke Yiddish and Hebrew, and perhaps some Polish, Russian or German; Jewish women typically spoke Yiddish and the local language, and were less likely to read any language except among the middle classes. Central and eastern European Jewry as a whole was centered linguistically not so much around Hebrew, which women typically could not read, regardless of their social status or geographic position, but Yiddish and religious ritual. For some educated Jews, cultivated German replaced Yiddish in this function. The extremely varied pattern of linguistic competence and behavior varied with class, location, gender and even politics: leftists were more likely than pious traditionalists to speak both Yiddish and a local language. And despite this seeming fragmentation, Jewish diaspora identities remained largely unchanged until the nineteenth century, when they changed as much because of emancipation as because of internal forces. This pattern of varied competence was found in many Jewish diaspora communities, including North American ones, though perhaps in slightly 
less extreme forms. Yiddish has outlasted German as a spoken language among North American Jews. The vast majority of younger Yiddish speakers today belong to Chassidic groups that practice varieties of separation from their surroundings, from neighborhood clusters, as of the Belzers in the Plateau Mont-Royal in Montreal, to the gated communities of various Chassidic groups in upstate New York. Yet Yiddish language and literature are being taught in colleges and universities across North America and Germany. The Forwards/Forverts is printed in Yiddish 32 as well as English and broadcasts news and a mixed literary and cultural program in Yiddish once a week. ${ }^{33}$

ANTI-GERMAN SENTIMENT, EXILE AND IDENTITY.

German-Polish identity is another thorny issue. Before 1939, generations of Christians who spoke both German and Polish lived on the territory of contemporary Poland, as well as western Belarus and northern Galicia. The Kashubes spoke Slavic Kashubian as well as German and Polish. The powerful volumes of Günther Grass's Danzig Trilogy demonstrate how these hybrid people and groups were forced to choose between being "German" and being "Polish" (the Kashubes were both, but then suddenly, neither), and the horrific personal as well as structural consequences of this enforced ethnic 'inner cleansing.' The ethnic and linguistic 'cleansing' of Silesia after 1945, for example, effected especially by a generation or two of Polish-only education for the many members of the formerly hybrid, truly transnational polyglot population who had chosen to be or were allowed to be 'Polish', substituted a (putatively) monoglot and monolithically Polish culture for a very old hybrid one..$^{34}$ The physical reminders of the germanophone presence in Silesia are German-language stone engravings in churches and on headstones, and in a much more shadowy way, the actual shadows left where, after the war, metal letters and signs in German were removed from facades which, in 1997, at least, still had not been resurfaced; and the ghostly remnants, in small towns, of commercial signs in German, often bearing 'German' names, above old garages, stables, shops and smithies. Except for some aging (and usually irredentist) émigrés, neither Germans nor Poles can, after a mere sixty years, imagine the hybrid identity and linguistic practice that characterized the region for dozens of generations: they have been cut apart, like conjoined twins that have been prised apart by a skillful violence. 


\section{NORTH AMERICAN PARALLELS}

The living and even growing practice of such languages and linguistically bound cultures as transnational forms articulates local agency and specificity in ways that require us to modify our understanding of metropolitan cultural capital and its flows 'outwards' towards putative 'peripheries.' A few more examples from the North American context will suffice to illustrate how inadequate such geographic metaphors can be: there are far more native speakers of Yiddish in North America than in Europe; the number of native speakers of Low German outside the original areas of 'Platt', 'Niederdeutsch' and so on is also not insignificant by comparison with the lands of origin. European languages and linguistically bound cultures other than English, French and Spanish flourished for centuries in North America. There are as many as a thousand native speakers of Scots Gaelic in Cape Breton, Nova Scotia today, 35 and though fewer than a hundred native speakers of Irish Gaelic remain on the Irish Shore of the Avalon Peninsula of Newfoundland, in both places Gaelic was the primary language of many communities well into the twentieth century: "There are known to have been Irish speakers in the District of Harbour Main as late as the beginning of this (the 20th) century. And folkloric accounts of Irish speakers from other areas of the Avalon Peninsula suggest that this was not an isolated phenomenon." 36 There is also the case of Bungee/Bungay/Red River dialect, a syncretic language based on Gaelic and Cree spoken on the Prairies 37 until at least the middle of the twentieth century and a parallel to Michif, the complex syncretic language based on French, Cree various other native languages, which is still spoken by around a thousand Métis. These long-lived local articulations of until-recently devalued cultural capital presented a bold face to the globalizing forces of English. They also provide reasons to question dominant models of cultural dissemination, influence and assimilation, partly because significant renewal projects have been undertaken to teach Gaelic to children in Nova Scotia ${ }^{38}$ and in Scotland, and undergraduates at Memorial University in Newfoundland.

I hope this paper has made a small contribution toward rethinking the marginal and the diasporic in Central European studies, toward projects of re-appropriating displaced/occluded pasts, of problematizing seemingly 'natural' categories such as national identity with a view to the potential of the category of the transnational, and in some very modest, perhaps only imaginary sense, by attempting to 
recuperate the specifics of lived practice from the tyrannical metanarratives that would efface them, of tikkun olam ['healing of the world']. ${ }^{39}$

\section{E N D NOTES}

1 One classic text is Milton M. Gordon, Assimilation in American Life (New York: Oxford University Press, 1964); a very different take can be found in Ronald Takaki, A Different Mirror. A History of Multicultural America (Boston/Toronto/London: Little, Brown and Company, 1993). Beyond these volumes, I am not going to try to survey the immense literature on this subject. For a good overview and select bibliography, see Laura Laubeová, "Melting Pot vs. Ethnic Stew," in: Carl Skutsch, ed. Encyclopedia of the World's Minorities, 3 vols. (New York: Routledge, 2005), II; article also available (with what appear to be superseded publishing details) at http://www.tolerance.cz/courses/ texts/melting.htm, accessed 26 January 2006.

2 See the sustained attack on the concept and effects of Canada's official policy of 'multiculturalism' in William Anselmi and Kosta Gouliamos, Happy Slaves. A Duologue on Multicultural Deficit (Toronto: Guernica Editions, 2005); on the other hand, see Bhikhu Parekh, Rethinking Multiculturalism. Cultural Diversity and Political Theory (London: Macmillan Press, 2000).

3 American Studies - Presidential Address to the American Studies Association, November 12, 2004", in: American Quarterly vol. 57, 1, March 2005, 17-57.

4 Young-Sun Hong, "The Challenge of Transnational History," posted 19 January 2006; accessed 25 January 2006 via http://www.hnet.org/ german/discuss/Trans/forum_trans_index.htm

5 David Palumbo-Liu and Hans Ulrich Gumbrecht, eds., Streams of Cultural Capital: Transnational Cultural Studies. Special issue of Stanford Literature Review, 1993 (reprint Palo Alto: Stanford University Press, 1997); introductory essay.

6 "Benefits of Diaspora," in the London Review of Books, vol. 27, no. 20; October 20th, 2005, 16-17. I would suggest that a semi-permanent state of war makes extraordinary intellectual, artistic or scientific work very difficult, and if mere fear or oppression from outside made people brilliant, then the embattled Israel of, say, 1948-1973 should have produced an inordinate number of geniuses in the following years, as Israel became more stable and secure.

$7 \quad$ See Scott Spector's article in this volume.

8 (Boston: Little Brown, 1951), 36-37.

9 See Wolfgang Hellish and Walter D. Kamphoefner, eds. German-American Immigration and Ethnicity in Comparative Perspective (Madison: Max Kade Institute for German-American Studies, 2004); Walter Kamphoefner, Germans in America (Teaneck, NJ: Holmes and Meier, 1994); Aaron Spencer Fogelman, Hopeful Journeys: German Immigration, Settlement, and Political Culture in Colonial America, 1717-1775 (Philadelphia: University of Pennsylvania Press, 1996); Steven M. Nolt, Foreigners in Their Own Land: Pennsylvania Germans in the Early Republic (University Park, PA: Pennsylvania State University Press, 2002); A.G. Roeber, Palatines, Liberty, and Property: German Lutherans in Colonial British America (Baltimore: The Johns Hopkins University Press, 1998). 
10 In 1914, around 10\% of the population of Alberta was of germanophone descent, and 'German' is still the third-largest ethnic group of origin in Alberta, after 'British Isles' and 'Ukrainian.'

11 See, for instance, Tobias Brinkmann on the hybrid identity of 'German Jews' in "The Dialectics of Ethnic Identity: German Jews in Chicago, 1850-1870", in: Helbich and Kamphoefer, eds., German-American Immigration, 44-68.

12 In 1860, 75\% of Milwaukee's population was of German origin. See, for example, Anke Ortlepp, "Auf denn, Ihr Schwestern!": Deutschamerikanische Frauenvereine in Milwaukee, Wisconsin, 1844-1914 = Transatlantische Historische Studien, 17 (Stuttgart: Franz Steiner Verlag, 2004).

13 A very popular nineteenth-century series of cartoon stories about two naughty boys that represents a Wilhelmine aesthetic of a sort that was also very popular in America. See the materials provided by Robert Godwin-Jones, Virginia Commonwealth University, at http://www.fln.vcu.edu/mm/mm-vor.html (accessed 22 February, 2006), and some images of the brewery at http://www.budweisertours.com/docs/StLouis/hours.htm, accessed 22 February, 2006 and the image at http://peter.koritschan.com/gallery/ older/afs9798/0145.JPG, accessed 22 February, 2006.

14 See their website at http://www.shaarhashomayim.org, accessed 22 February, 2006.

15 See the Montreal synagogue's brief history at http://www.spanishportuguesemtl.org/synagogue/about.shtml; and the New York one at http://www.shearith-israel.org/folder/main_frames_new.html, under Learning Center, History, both accessed 22 February, 2006.

16 The single exception on 'German' soil having been, famously, the Slavic Sorb minority in the south-eastern GDR, whose language had and has 'official' status and whose inclusion in the united Germany should suffice to produce a significant if small fissure in German national self-understanding.

17 On Mennonite Low German, for example, see Jack Thiessen, Studien zum Wortschatz der kanadischen Mennoniten = Deutsche Dialektgeographie, Bd. 64 (Marburg: Erwert, 1963), Jakob Warkentin Goerzen's self-published study Low German in Canada: a study of "Plautditsch" (Edmonton: Goerzen, 1972), also available at the University of Toronto. Also Doreen Klassen, Singing Mennonite: Low German Songs among the Mennonites (Winnipeg: University of Manitoba Press, 1989); on the same topic in the American Mid-West, see Birgit Mertens, Vom (Nieder-)Deutschen zum Englischen: Untersuchungen zur sprachlichen Assimilation einer ländlichen Gemeinde im mittleren Westen Amerikas (Heidelberg: C. Winters, 1994) and Alexandra Jacob, Niederdeutsch im mittleren Westen der USA: Auswanderungsgeschichte, Sprache, Assimilation (Bielefeld: Verlag für Regionalgeschichte, 2002), and in South America, Kai Rohkohl, Die plautdietsche Sprachinsel Fernheim/Chaco (Paraguay): Dokumentation des Sprachverhaltens einer russlanddeutschen Mennonitenkolonie $=$ Schriftenreihe der Kommission für Ostdeutsche Volkskunde in der Deutschen Gesellschaft für Volkskunde e.V. ; Bd. 64, (Marburg: Elwert, 1993).

18 See for example Ludger Kremer, Grenzmundarten und Mundartgrenzen: Untersuchungen zur wortgeographischen Funktion der Staatsgrenze im ostniederländischwestfälischen Grenzgebiet (Vienna/Cologne: Böhlau, 1979), which studies the 
function of the state border between Germany and the Netherlands in 'dialect' formation. In this discourse, state borders make various 'dialects' of what once had been a single language.

19 A university founded by dissenting scholars (such as historian Charles Beard, philosopher John Dewey, and economists Thorstein Veblen and James Harvey Robinson) in Manhattan in 1919; a second division was founded as The University in Exile in 1933, and served as a refuge for many Central European scholars, among them many Jews. See http://www.newschool.edu/ history.html, accessed 20 February, 2006.

20 See, for example, the cover of German-American Immigration, on which is reproduced in German a polychrome print of "Das Star-Spangled Banner", issued during the Civil War by H. de Marsan Publisher, No. 54 Chatham Street, New York; probably translated by Hermann Seele of New Braunfels, Texas who published a similar version in 1851 . The German version is also in a choral book of 1890 and was sung in the bilingual public schools of Indianapolis until 1917, according to the inside of the dust jacket. While this latter assertion corresponds to my own knowledge about German-language schooling in pre-1917 Ontario, one would like a source!

21 For the example of how Pfälzer (inhabitants of the Palatinate) became 'Germans' at some point after they reached America, see Philip Otterness, Becoming German: The 1709 Palatine Migration to New York (Ithaca and London: Cornell University Press, 2004); for Westphalians see Walter Kamphoefner, The Westphalians: From Germany to Missouri (Princeton: Princeton University Press, 1987). There is a similar community of Hessians in eastern Ontario (descended from demobilized British 'legionnaires' from the American War of Independence) who also 'became Germans' when that was the only category that made sense to outsiders.

22 See, again, Hobsbawm, "Diaspora," in which he notes that urban Jews all over eastern Europe tended to identify with and learn or use German - the language of Culture in the nineteenth century - rather than local languages such as Polish or Ruthenian, partly because of the relative ease with which a Yiddish-speaker could learn German, partly because of the superior international prestige of the language of Goethe and Schiller.

23 Russell Kazal, Becoming Old Stock: The Paradox of German-American Identity (Princeton and Oxford: Princeton University Press, 2004).

24 For a series of studies on European Jews in South America, see Achim Schrader and Karl Heinrich Rengstorf, eds., Europäische Juden in Lateinamerika (St. Ingbert: W.J. Röhrig, 1989), including a useful (but dated) bibliography by Achim Schrader and Thomas Blank for the study of German Jews in Latin America, 473-503.

25 See the links to university Yiddish departments and other Yiddish resources listed by the National Yiddish Book Center, at http:// www.yiddishbookcenter.org/+15, accessed 26 February, 2006.

26 (Penguin, 2005).

27 The best short definition I have found is Ruben Frankenstein's at http://reissner-guben.org/w2005/ruben_yekkes.html, with rudimentary bibliography; accessed 26 January, 2006. 
28 From Hysterics. An Online Art Magazine, http://www.hysterics.art.pl/art/24/ sentence.html

29 "Rynek in Lubaczow. Josh Heilman's Memories." Compiled by Eva Floersheim, 15240 Shadmot Dvorah, Lower Galilee, Israel, November 2002.

30 A younger sister of the intrepid Eszter Wajszblum, who was executed a few days before the liberation of Auschwitz for attempting to blow up the ovens. See the short text at http://www.peripheries.net/i-donqui2.htm, accessed 26 January, 2006.

31 See Anna Heilman, Never Far Away: The Auschwitz Chronicles of Anna Heilman (Calgary: University of Calgary Press, 2001).

32 http://yiddish.forward.com/

33 http://yiddish.forward.com/radio/index.html; in the New York area, AM 570 after Shabbat on Saturdays, complete with very Central-European sounding accordion music as a signature tune at the beginning and end, graced by a klezmer clarinet.

34 See, for Silesia, Wlodzimierz Borodjiez and Hans Lemberg, eds., "Unsere Heimat ist uns ein fremdes Land geworden?": Die Deutschen östlich von Oder und Neisse 1945-1950: Dokumente aus polnischen Archiven, vol. 2: Zentralpolen, Wojwodschaft Schlesien (Oberschlesien). Marburg: Herder-Institut, 2003.

35 "At one point a motion was tabled in Parliament that Gaelic (Scottish Gaelic and Irish not having been seen as distinct at the time) be made the third official language of the Dominion [of Canada - AG] but did not pass. More settlers came to Canada from Scotland than from any other country, and Gaelic was widespread. In some parts of Nova Scotia, Ontario and the North, it was not possible to be understood in English, and Presbyterian ministers who could not speak Gaelic were not even considered for many congregations. [...] The last native speaker of Gaelic in Ontario [i.e., native Ontarian - AG] died in 2001." From http://en.wikipedia.org/wiki/Canadian_Gaelic\#Origins, accessed 26 January 2006. For an obituary story from the Toronto Star (Saturday, Dec. 1, 2001) on Alec McDonald, this last native Ontarian speaker of Gaelic, see http://www.electricscotland.com/history/canada/mcdonald_alec.htm, accessed 8 February 2006.

36 Cyril Byrne, "Irish Language in Newfoundland" in Gordon W. MacLennan, ed., Proceedings of the First North American Congress of Celtic Studies (Ottawa, 26th-30th March 1986; Ottawa: Chair of Celtic Studies, University of Ottawa, 1988), 7. Furthermore, "Records from Newfoundland's Courts, where defendants often required Irish-speaking interpreters, lend support to Dr. Byrne's assertion that, at least until the 1820s, the dominant language of the Avalon Peninsula was Irish rather than English. Ecclesiastical documents bolster his case. In a 1791 letter to Dublin requesting a Franciscan missionary for the parishes of St. Mary's and Trepassey, Bishop James O'Donel cautions: 'It is absolutely necessary that he should speak Irish.' Field research around the ancestral Byrne homestead at Holyrood, on Conception Bay, revealed that native speakers passed down Irish to their Newfoundland-born children and grandchildren. Dr. Byrne learned that Tom Wade, a maternal great-grandfather, was an Irish speaker. Wade himself had never set foot in Ireland - his grandmother, Bridget Riley, was an immigrant from South Kilkenny whose family settled in Kitchuses, across Conception Bay 
from Holyrood." Brian McGinn, "Newfoundland. The Most Irish Place outside of Ireland" at irishdiaspora.net, The Irish Diaspora Studies Scholarly Network, at http:// www.irishdiaspora.net/vp01.cfm?outfit=ids\&requesttimeout=500\&folde $\underline{\mathrm{r}=158 \& \text { paper }=159}$, accessed 8 February 2006.

37 See the short article, with bibliography, at http://en.wikipedia.org/wiki/Bungee_language, accessed 26 January 2006.

38 See the initiative to offer free Gaelic courses to all school-age children in Nova Scotia at the Gaelic College: http:/ / www.gaeliccollege.edu/ 